\title{
Efektivitas Implementasi Pemungutan PBB P2 Kota Pontianak
}

\author{
Elsa Sari Yuliana, Tashadi Tarmizi, \& Soraya \\ Jurusan Akuntansi, Politeknik Negeri Pontianak \\ Jalan Ahmad Yani Pontianak 78124 \\ Email: elsa_sariyuliana@yahoo.com
}

\begin{abstract}
Abstrak: Penelitian ini bertujuan untuk mengkaji efektivitas implementasi pajak bumi dan bangunan perdesaan dan perkotaan sejak ditetapkan sebagai pajak daerah Kota Pontianak. Dalam penelitian ini akan dilihat efektivitas dari segi ketercapaian target pajak bumi dan bangunan terhadap realisasi penerimaan pajak. Juga akan dilihat upaya apa saja yang telah dilakukan oleh Pemerintah Kota Pontianak dalam mengoptimalisasikan implementasi pajak bumi dan bangunan di Kota Pontianak, serta apa pandangan masyarakat selaku wajib pajak terhadap upaya yang dibangun oleh pemerintah. Diharapkan dari hasil penelitian ini akan tersusun kesepahaman antara Pemerintah Kota Pontianak dan wajib pajak mengenai manfaat optimalisasi penerimaan pajak bumi dan bangunan di Kota Pontianak. Hal ini kelak akan mendukung tercapainya pembangunan daerah yang berkelanjutan di Kota Pontianak.
\end{abstract}

Kata Kunci: $P B B$ P2, Efektivitas, Kontribusi.

\section{PENDAHULUAN}

Kota Pontianak merupakan Ibu Kota Propinsi dan merupakan salah satu dari 14 kota/kabupaten di Propinsi Kalimantan Barat. Kota Pontianak terletak pada Lintasan Garis Khatulistiwa dengan ketinggian berkisar antara 0,1 sampai 1,5 meter diatas permukaan laut. Kota ini dipisahkan oleh Sungai Kapuas Besar, Sungai Kapuas Kecil, dan Sungai Landak. Dengan demikian Kota Pontianak terbagi atas tiga belahan.

Secara administratif, kota Pontianak dibagi atas enam kecamatan, yaitu Pontianak Selatan, Pontianak Timur, Pontianak Barat, Pontianak Utara, Pontianak Kota, dan Pontianak Tenggara, yang kemudian dibagi lagi menjadi 29 kelurahan. Berdasarkan sensus penduduk pada tahun 2000, penduduk Kota Pontianak berjumlah 554.764 jiwa, terdiri dari
$277.971(50,1 \%)$ laki-laki dan 276.793 $(49,9 \%)$ perempuan.

Pemerintahan Kota yang telah berumur 246 tahun pada tahun 2017 ini telah memperoleh opini wajar tanpa pengecualian (WTP) untuk laporan keuangan tahun 2015 dan mendapatkan opini wajar tanpa pengecualian dengan paragraf penjelas (WTP DPP) mulai tahun 2011 hingga 2014 dari Badan Pemeriksa Keuangan Republik Indonesia (BPK RI). Opini ini merupakan opini yang sangat baik yang diberikan oleh BPK RI atas kewajaran penyajian laporan keuangan yang diperiksanya.

Kota Pontianak menerapkan PBB P2 sebagai pajak daerahnya sejak tahun 2012 dengan diterbitkannya Peraturan Daerah Nomor 4 Tahun 2012. Hal ini menindaklanjuti Undang-Undang Nomor 28 Tahun 2009 tentang Pajak Daerah dan 
Retribusi Daerah. UU Nomor 28 Tahun 2009 ini merupakan titik tolak pengalihan PBB P2 menjadi pajak daerah. Hal ini berarti kegiatan proses pendataan, penilaian, penetapan, pengadministrasian, pemungutan/ penagihan, dan pelayanan PBB P2 diselenggarakan oleh pemerintah daerah.

Pajak merupakan sumber utama dari pendapatan daerah. Begitu juga di Kota Pontianak, terlihat pada Tabel 1. persentase sumbangan pajak daerah terhadap pendapatan daerah rata-rata sebesar $71,41 \%$ dalam 5 (lima) tahun terakhir.

Berdasarkan data tabel 1, pemerintah akan sangat berupaya untuk mengoptimalkan penerimaan pajak daerah setiap tahunnya. Maka dengan diterbitkannya Perda Kota Pontianak No 6 Tahun 2010, merupakan dasar hukum yang sangat kuat untuk pemerintah daerah mengoptimalkan lagi potensi pajak daerahnya. Terlebih dengan dijadikannya PBB P2 sebagai salah satu sumber pajak daerah.

Tabel 1. Persentase Pajak Daerah Terhadap Pendapatan Daerah di Kota Pontianak dalam tahun 2012 $-2016$

\begin{tabular}{|c|c|c|c|c|c|}
\hline \multirow{2}{*}{ Keterangan } & \multicolumn{5}{|c|}{ Tahun } \\
\hline & 2012 & 2013 & 2014 & 2015 & 2016 \\
\hline Pendapatan Daerah & $208.626 .660 .840,82$ & $265.271 .762 .170,33$ & $298.768 .480 .274,53$ & $334.754 .033 .020,48$ & $378.675 .094 .000,00$ \\
\hline Pajak Daerah & $162.782 .492 .225,00$ & 179.655.427.197,00 & $203.165 .655 .899,00$ & $240.452 .113 .349,00$ & $270.700 .000 .000,00$ \\
\hline Persentase & $78,02 \%$ & $67,73 \%$ & $68,00 \%$ & $71,83 \%$ & $71,49 \%$ \\
\hline Rata2 Persentase & & & $71,41 \%$ & & \\
\hline
\end{tabular}

Melihat gambaran diatas sangat menarik bagi penulis untuk membuat penelitian mengenai kajian upaya-upaya yang telah dilakukan Pemerintah Kota Pontianak dalam mengoptimalkan efektivitas implementasi pajak bumi dan bangunan Perdesaan dan Perkotaan di Kota Pontianak. Penulis juga ingin melihat pandangan masyarakat Kota Pontianak yang merupakan wajib pajak PBB P2 mengenai upaya-upaya yang telah dilakukan oleh Pemerintah Kota dalam mengoptimalkan penerimaan pajak daerahnya, khususnya PBB P2.

Oleh karena alasan di atas, penulis mengangkat judul penelitian "Efektivitas Implementasi Pajak Bumi dan Bangunan Perdesaan dan Perkotaan di Kota Pontianak".

\section{Pertanyaan Penelitian.}

Bagaimana perkembangan penerimaan Pajak Bumi dan Bangunan Perdesaan dan
Perkotaan di Kota Pontianak sejak tahun 2012-2016?; 2) Bagaimana kontribusi penerimaan Pajak Bumi dan Bangunan Perdesaan dan Perkotaan terhadap Pajak Daerah di Kota Pontianak sejak tahun 2012-2016?

Tujuan Penelitian. Tujuan khusus penelitian ini diharapkan dapat mendorong optimalisasi kinerja Pemerintah Kota Pontianak dalam mengelola potensi pajak daerah khususnya pajak bumi dan bangunan Pemerintah Kota Pontianak untuk mengoptimalkan pencapaian target penerimaan Pajak Bumi dan Bangunan Perdesaan dan Perkotaan di Kota Pontianak.

\section{KAJIAN LITERATUR}

\section{Pengertian Efektivitas}

Kata efektivitas berasal dari kata efektif yang menurut KBBI Daring (2017) bermakna (1) ada efeknya (akibatnya, 
pengaruhnya, kesannya), (2) manjur atau mujarab - bila tentang obat, (3) dapat membawa hasil; berhasil guna; mangkus bila tentang usaha, tindakan, (4) mulai berlaku - bila tentang undang-undang, peraturan.

Kurniawan (2005) menyampaikan bahwa efektivitas adalah kemampuan melaksanakan tugas, fungsi (operasi kegiatan program atau misi) daripada suatu organisasi atau sejenisnya yang tidak adanya tekanan atau ketegangan diatara pelaksananya.

Mahmudi (2005) menjelaskan definisi efektivitas adalah hubungan antara output dengan tujuan, semakin besar kontribusi (sumbangan) output terhadap pencapaian tujuan, maka semakin efektif organisasi, program atau kegiatan.

Berdasarkan pendapat diatas, penulis menyimpulkan bahwa efektivitas adalah ketercapaian atas hasil yang diharapkan oleh suatu organisasi yang dalam hal penelitian ini dapat diukur dengan tercapainya target penerimaan pemungutan PBB P2 oleh Pemerintah Kota Pontianak.

\section{Implementasi}

Kata implementasi menurut KBBI Daring (2017) bermakna pelaksanaan; penerapan. Sejalan dengan KBBI, Usman (2002) menyebutkan implementasi adalah bermuara pada aktivitas, aksi, tindakan atau adanya mekanisme suatu sistem, implementasi bukan sekedar aktivitas, tapi suatu kegiatan yang terencana dan untuk mencapai tujuan kegiatan.

Setiawan (2004) berpendapat bahwa implementasi adalah perluasan aktivitas yang saling menyesuaikan proses interaksi antara tujuan dan tindakan untuk mencapainya serta memerlukan jaringan pelaksana, birokasi yang efektif.
Berdasarkan pendapat-pendapat diatas maka penulis menyimpulkan bahwa implementasi adalah suatu proses terencana yang telah dipersiapkan dengan matang dan dilakukan oleh organisasi untuk mencapai tujuannya.

\section{Pajak Bumi dan Bangunan Perdesaan dan Perkotaan}

\section{Pengertian Pajak Bumi dan Bangunan Perdesaan Perkotaan (PBB P2)}

Pajak Bumi dan Bangunan Perdesaan Perkotaan (PBB P2) yang berdasarkan UU Nomor 28 Tahun 2009 telah ditetapkan sebagai salah satu pajak yang hak pengelolaannya ada pada daerah. Pengertian Pajak Bumi dan Bangunan Perdesaan Perkotaan berdasarkan Perda Kota Pontianak Nomor 6 Tahun 2010 adalah pajak atas bumi dan/atau bangunan yang dimiliki dikuasai, dan/atau dimanfaatkan oleh orang pribadi atau Badan, kecuali kawasan yang digunakan untuk kegiatan usaha perkebunan, perhutanan, dan pertambangan.

\section{Objek PBB P2}

Objek PBB P2 adalah bumi dan/atau bangunan. Pengertian Bumi menurut Perda Kota Pontianak No 6 Tahun 2010 pasal 62 ayat 2 adalah permukaan bumi yang meliputi tanah dan perairan pedalaman serta laut wilayah kabupaten/kota, dan pengertian Bangunan adalah konstruksi teknik yang ditanam atau dilekatkan secara tetap pada tanah dan/atau perairan pedalaman dan/atau laut.

Termasuk pengertian Bangunan sebagaimana disampaikan pada Pasal 62 ayat 3 adalah:

1. Jalan lingkungan yang terletak dalam satu kompleks bangunan seperti hotel, 
pabrik, dan emplasemennya, yang merupakan suatu kesatuan dengan kompleks Bangunan tersebut;

2. Jalan tol;

3. Kolam renang;

4. Pagar mewah;

5. Tempat olahraga;

6. Galangan kapal, dermaga;

7. Taman mewah;

8. Tempat penampungan/kilang minyak, air dan gas, pipa minyak; dan

9. Menara.

\section{Subjek PBB P2}

Subjek PBB P2 berdasarkan Perda Kota Pontianak No 6 Tahun 2010 Pasal 63 adalah seorang pribadi atau Badan yang secara nyata mempunyai suatu hak atas Bumi dan/atau memperoleh hak atas bumi, dan/atau memiliki, menguasai, dan/atau memperoleh manfaat atas Bangunan. Pengertian subjek pajak PBB P2 mendasari penentuan wajib pajak PBB P2.

\section{Dasar Pengenaan dan Tarif PBB P2}

Berdasarkan Perda Kota Pontianak No 6 Tahun 2010, dasar pengenaan PBB P2 adalah nilai jual objek pajak (NJOP). Besarnya NJOP ditetapkan setiap 3 (tiga) tahun, kecuali untuk objek pajak tertentu dapat ditetapkan setiap tahun sesuai dengan perkembangan wilayahnya. Tarif PBB P2 ditetapkan sebesar $0,3 \%$ (nol koma tiga persen).

Penentuan besar pokok PBB P2 terutang dihitung dengan cara mengalikan tarif dengan dasar pengenaan pajak yaitu NJOP dan dikurangi nilai jual objek pajak tidak kena pajak (NJOPTKP) sebesar Rp 10.000.000,- (sepuluh juta rupiah) untuk setiap objek pajak.

\section{Penelitian Terdahulu yang Berkaitan Dengan Variabel Penelitian}

Penelitian sebelumnya yang berkaitan dengan objek penelitian yaitu PBB P2 pernah dilakukan di Kota Pontianak oleh Al-Qadrie (2016) dengan judul Implementasi Kebijakan Pemungutaan Pajak Bumi dan Bangunan Pedesaan dan Perkotaan di Kota Pontianak. Namun dalam penelitiannya Al-Qadrie menitikberatkan pada implementasi kebijakan pemungutan PBB P2, yang mana hasilnya adalah implementasi kebijakan pemungutan PBB P2 telah berjalan dengan baik tetapi masih ada kendala, yakni sosialisasi kepada masyarakat secara langsung, kurangnya sumberdaya manusia dalam mengimplementasikan kebijakan, masih kurangnya sumber daya infrastruktur terutama sumber daya data mengenai data objek dan subjek pajak yang terkadang berbeda di lapangan dengan surat SPPT yang diterbitkan oleh DISPENDA Kota Pontianak, serta belum maksimalnya dari segi pengawasan.

\section{METODE PENELITIAN}

Penelitian ini adalah riset eksploratori dengan teknik analisa deskriptif. Menurut Umar (2008), riset eksporatori atau biasa disebut dengan penjajakan mengenai suatu permasalahan yang belum jelas atau masih relatif baru. Sedangkan analisa deskriptif bertujuan untuk memaparkan variabelvariabel yang diteliti. Pendekatan yang digunakan dalam penelitian ini adalah pendekatan kuantitatif. Pendekatan kuantitatif adalah untuk memberikan gambaran secara sistematis, faktual dan akurat mengenai fakta-fakta dan keadaan sebenarnya tentang perkembangan dan kontribusi penerimaan pajak daerah oleh Pemerintah Kota Pontianak, khususnya penerimaan PBB P2. 
Untuk menjawab rumusan masalah pertama dan kedua maka penulis dengan pertimbangan penggunaan data yang mutakhir penelitian ini menggunakan data sekunder dalam bentuk ringkasan realisasi APBD Kota Pontianak selama 5 (lima) tahun anggaran terakhir yaitu dari tahun 2012 hingga 2016.

Pemilihan Kota Pontianak sebagai subjek penelitian dengan alasan opini wajar tanpa pengecualian (WTP) yang diberikan Badan Pemeriksa Keuangan (BPK) atas laporan keuangan Pemerintah Kota Pontianak. BPK merupakan badan pemeriksa keuangan tertinggi di Indonesia, sehingga opini ini merupakan penghargaan tertinggi di Indonesia dalam hal akuntabilitas keuangan pemerintah.

Dengan pertimbangan penggunaan data yang mutakhir penelitian ini menggunakan data sekunder dalam bentuk ringkasan realisasi APBD Kota Pontianak selama 5 (lima) tahun anggaran terakhir yaitu dari tahun 2009 hingga 2013. Teknik pengambilan sampel dalam penelitian ini adalah menggunakan metode purposive sampling yakni pemilihan sampel dari populasi berdasarkan kriteria tertentu, dengan pertimbangan/judgment tertentu (Jogiyanto: 2007). Pemilihan Kota Pontianak sebagai subjek penelitian dengan alasan opini wajar tanpa pengecualian (WTP) yang diberikan Badan Pemeriksa Keuangan (BPK) atas laporan keuangan Pemerintah Kota Pontianak. BPK merupakan badan pemeriksa keuangan tertinggi di Indonesia, sehingga opini ini merupakan penghargaan tertinggi di Indonesia dalam hal akuntabilitas keuangan pemerintah.

Teknik Pengumpulan dan Analisis Data
Data yang digunakan dalam penelitian ini adalah Laporan Realisasi APBD tahun 2012-2016 yang diperoleh dari Dinas Pendapatan Daerah Kota Pontianak. Sehubungan data yang diperlukan dalam penelitian ini yang merupakan data sekunder, maka pengumpulan data dilakukan dengan memperoleh data Laporan Realisasi Anggaran (LRA) Kota Pontianak tahun 2012-2016.

Teknik analisa data yang akan digunakan dalam penelitian ini adalah analisa data deskriptif. Menurut Umar (2008: 105), analisis deskriptif diperlakukan pada variabel-variabel penelitian, tetapi sifatnya sendiri, tidak dikaitkan dengan variabel lain. Berdasarkan variabel tersebut, analisis dapat dilakukan untuk mendapatkan informasi mengenai banyak hal. Sejalan dengan pendapat Umar, Jogiyanto (2007: 163) menjabarkan statistik deskriptif sebagai statistik yang menggambarkan fenomena atau karakteristik dari data. Karakteristik data yang digambarkan adalah karakteristik distribusinya.

\section{HASIL DAN PEMBAHASAN}

Hasil penelitian ini adalah kontribusi dan efektivitas Pajak Bumi dan Bangunan Perdesaan dan Perkotaan (PBB P2) di Kota Pontianak. Data yang diperoleh sejak tahun 2012 hingga tahun 2016 melalui Laporan Realisasi Anggaran Pemerintah Kota Pontianak. Adapun data yang terkumpul disajikan pada tabel 2 .

Berdasarkan dari tabel 2. terlihat bawah terjadi peningkatan dari tahun ke tahun atas penerimaan PBB P2 di Kota Pontianak. Dari Rp14.766.277.121,00 pada 
tahun 2012, menjadi Rp15.550.794.427,00

pada tahun $2015 \quad$ menjadi

pada tahun 2013, meningkat terus hingga Rp25.000.000.000,00.

Tabel 2. Rekapitulasi Penerimaan PBB P2 terhadap Pajak Daerah

\begin{tabular}{lccrrr}
\hline \multirow{2}{*}{ Keterangan } & \multicolumn{5}{c}{ Tahun } \\
\cline { 2 - 6 } & $\mathbf{2 0 1 2}$ & $\mathbf{2 0 1 3}$ & $\mathbf{2 0 1 4}$ & \multicolumn{1}{c}{$\mathbf{2 0 1 5}$} & \multicolumn{1}{c}{$\mathbf{2 0 1 6}$} \\
\hline PBB P2 & $14.766 .277 .121,00$ & $15.550 .794 .4427,00$ & $18.253 .564 .046,00$ & $23.513 .598 .843,00$ & $25.000 .000 .000,00$ \\
Pajak Daerah & $162.782 .492 .225,00$ & $179.655 .427 .197,00$ & $203.165 .655 .899,00$ & $240.452 .113 .349,00$ & $270.700 .000 .000,00$ \\
\hline \multicolumn{2}{l}{ Sumber: Data diolah } & & & &
\end{tabular}

Tabel 3. Trend Penerimaan PBB P2 Kota Pontianak Tahun 2012 - 2016

\begin{tabular}{lcrrrr}
\hline \multirow{2}{*}{ Keterangan } & \multicolumn{5}{c}{ Tahun } \\
\cline { 2 - 6 } & $\mathbf{2 0 1 2}$ & $\mathbf{2 0 1 3}$ & $\mathbf{2 0 1 4}$ & \multicolumn{1}{c}{$\mathbf{2 0 1 5}$} & $\mathbf{2 0 1 6}$ \\
\hline PBB P2 & $14.766 .277 .121,00$ & $15.550 .794 .4427,00$ & $18.253 .564 .046,00$ & $23.513 .598 .843,00$ & $25.000 .000 .000,00$ \\
Peningkatan & & $784.517 .306,00$ & $2.702 .769 .619,00$ & $5.260 .034 .797,00$ & $1.486 .401 .157,00$ \\
\hline Rata2 Peningkatan & & \multicolumn{5}{c}{$2.558 .430 .720,00$} \\
\hline
\end{tabular}

Sumber: Data diolah

Tabel 4. Kontribusi PBB P2 terhadap Pajak Daerah Kota Pontianak Tahun 2012 - 2016

\begin{tabular}{|c|c|c|c|c|c|}
\hline \multirow{2}{*}{ Keterangan } & \multicolumn{5}{|c|}{ Tahun } \\
\hline & 2012 & 2013 & 2014 & 2015 & 2016 \\
\hline PBB P2 & $14.766 .277 .121,00$ & $15.550 .794 .4427,00$ & $18.253 .564 .046,00$ & $23.513 .598 .843,00$ & $25.000 .000 .000,00$ \\
\hline Pajak Daerah & $162.782 .492 .225,00$ & 179.655.427.197,00 & $203.165 .655 .899,00$ & $240.452 .113 .349,00$ & $270.700 .000 .000,00$ \\
\hline Persentase & $9,07 \%$ & $8,66 \%$ & $8,98 \%$ & $9,64 \%$ & $9,24 \%$ \\
\hline Rata2 Persentase & \multicolumn{5}{|c|}{$9,12 \%$} \\
\hline
\end{tabular}

Sumber: Data diolah

Tabel 5. Klasifikasi Kriteria Kontribusi

\begin{tabular}{cc}
\hline Persentase & Kriteria \\
\hline $0,00-10 \%$ & Sangat Kurang \\
$10,10-20 \%$ & Kurang \\
$20,10-30 \%$ & Sedang \\
$30,10-40 \%$ & Cukup Baik \\
$40,10-50 \%$ & Baik \\
Di atas $50 \%$ & Sangat Baik \\
\hline
\end{tabular}

Sumber: Tim Litbang Depdagri-Fisipol UGM 1991 (dalam Yulia Anggara Sari, 2011).

\section{Perkembangan Penerimaan PBB P2 Kota Pontianak Tahun Anggaran 2012 - 2106}

Perkembangan penerimaan Pajak Bumi dan Bangunan Perdesaan dan Perkotaan efektif menjadi salah satu sumber penerimaan pajak daerah pemerintah Kota Pontianak sejak tahun 2012. Adapun tren atau perkembangan penerimaan PBB P2, dapat dilihat pada tabel 3.

Tren penerimaan PBB P2 selalu meningkat dari tahun 2012 hingga tahun 2015 terlihat dari tabel 3, terjadi peningkatan sebesar Rp784.517.306,00 pada tahun 2013 dari penerimaan pada tahun 2012 yang sebesar Rp14.766.277.121,00. Pada tahun 2014 terjadi peningkatan kembali sebesar Rp2.702.769.619,00 menjadi Rp18.253.564.046,00 hal yang sama terlihat juga pada tahun 2015, yang mana terjadi peningkatan yang cukup signifikan yaitu sebesar Rp5.260.034.797,00 menjadi Rp23.513.598.843,00

Pada tahun 2016 tetap terjadi peningkatan walau menurun dari tahun sebelumnya, sebesar Rp1.486.401.157,00 menjadi Rp25.000.000.000,00. Rata-rata peningkatan penerimaan PBB P2 sebesar Rp2.558.430.720,00 per tahun sejak tahun 2012 hingga tahun 2016.

\begin{tabular}{|c|c|c|}
\hline Kontribusi & PBB & terhadap \\
\hline Penerimaan & Pajak & Daerah \\
\hline
\end{tabular}


Kontribusi PBB P2 Kota Pontianak terhadap total penerimaan Pajak Daerah dapat dilihat dalam tabel 4.

Berdasarkan tabel tersebut kontribusi PBB P2 terhadap Pajak Daerah sejak tahun 2012 hingga tahun 2016 bergerak pada 8 10\%. Pada tahun 2012 kontribusi sebesar 9,07\%, ini adalah tahun pertama PBB P2 dipungut oleh Pemerintah Kota Pontianak, jadi ini adalah tahun peralihan dari sebelumnya yang merupakan pajak pemerintah pusat. Pada tahun 2013 terjadi penurunan kontribusi sebesar $0,41 \%$ menjadi 8,66\%, meskipun sebenarnya besaran penerimaan PBB P2 pada tahun 2013 mengalami peningkatan.

Pada tahun 2014, terjadi peningkatan kembali sebesar $0,32 \%$ menjadi $8,98 \%$. Sama halnya dengan tahun 2013, pada tahun 2014 ini pun terjadi peningkatan penerimaan PBB P2. Tahun 2015 terjadi peningkatan yang cukup besar dari tahun 2014 yaitu sebesar $0,66 \%$ atas kontribusi PBB P2 terhadap pajak daerah. Pada tahun ini terjadi peningkatan penerimaan pajak daerah yang cukup signifikan dari tahun sebelumnya.

Pada tahun 2016, terjadi penurunan $0,4 \%$ dari kontribusi tahun sebelumnya yang sebesar 9,64\% menjadi 9,24\%. Di tahun ini terjadi peningkatan realisasi PBB P2 dan pajak daerah Kota Pontianak.

Rata-rata selama tahun amatan (2012 - 2016) kontribusi PBB P2 terhadap Pajak Daerah Kota Pontianak berkisar 9,12\%. Jika dimasukkan dalam klasifikasi kategori kategori menurut Tim Litbang DepdagriFisipol UGM 1991 (dalam Yulia Anggara Sari, 2011), maka 9,12\% masuk pada kategori sangat kurang.

\section{SIMPULAN DAN SARAN}

\section{Simpulan}

Simpulan yang diperoleh dari penelitian ini adalah sebagai berikut.

Pertama. Terjadi peningkatan penerimaan PBB P2 di Kota Pontianak sejak tahun 2012 hingga tahun 2015, dengan rata-rata peningkatan penerimaan PBB P2 sebesar Rp2.558.430.720,00 per tahun.

Kedua. Kontribusi PBB P2 terhadap Pajak Daerah sejak tahun 2012 hingga tahun 2016 bergerak pada 8,66\% - 9,64\%. Kontribusi terendah ada pada tahun 2013, dan tertinggi pada tahun 2015. Namun berdasarkan klasifikasi kategori kontribusi, rentang kontribusi 8,66\% - 9,64\% masuk dalam kategori "sangat kurang".

\section{Saran}

Saran yang dalam penelitian ini adalah sebagai berikut.

Pertama. Pemerintah Kota Pontianak agar dapat meningkatkan kegiatan berupa edukasi kepada masyarakat agar masyarakat dapat tambah sadar pajak, untuk meningkatkan penerimaan pajak daerah, dalam hal ini PBB P2.

Kedua. Tambah daerah amatan, seperti seluruh kota/ kabupaten di Provinsi Kalimantan Barat.

Ketiga. Menambah analisa seperti pengumpulan pendapat pengambil kebijakan, dan masyarakat pembayar pajak.

\section{REFERENSI}

Al-Qadrie, Nanda Muhammad Shauqie. (2016). Implementasi Kebijakan Pemungutan Pajak Bumi dan Bangunan Pedesaan dan Perkotaan di Kota Pontianak, tersedia [online] di: http://jurmafis.untan.ac.id/index.php/p ublika/article/view/1075 diakses pada 
tanggal 13 Mei 2017, pukul 10.32 wib.

Jogiyanto. (2007). Metodologi Penelitian

Bisnis: Salah Kaprah dan Pengalaman-Pengalaman.

Yogyakarta: BPFE.

KBBI Daring. (2017). Definisi Efektif, tersedia [online] di: http://kbbi.web.id/efektif.html diakses pada tanggal 13 Mei 2017, pukul 12.03 wib.

KBBI Daring. (2017). Definisi Implementasi, tersedia [online] di: http://kbbi.web.id/implementasi.html diakses pada tanggal 13 Mei 2017, pukul 12.05 wib.

Kurniawan, Agung. (2005). Transformasi Pelayanan Publik, Yogyakarta: Pembaharuan.

Mahmudi. (2005). Manajemen Kinerja Sektor Publik, Yogyakarta: UPP AMP YKPN.

Peraturan Daerah Kota Pontianak Nomor 6 Tahun 2010 Tentang Pajak Daerah Kota Pontianak.

Peraturan Daerah Kota Pontianak Nomor 4 Tahun 2012 Tentang Perubahan Perda Nomor 6 Tahun 2010.

Setiawan, Guntur. (2004). Implementasi Dalam Birokrasi Pembangunan, Jakarta: Balai Pustaka.

Umar, Husein. (2008). Desain Penelitian Akuntansi Keperilakuan. Jakarta: Rajawali Pers.

Undang-Undang Nomor 28 Tahun 2009 Tentang Pajak Daerah dan Retribusi Daerah.
Usman, Nurdin, (2002), Konteks Implementasi Berbasis Kurikulum, Jakarta: Grasindo.

Yulia, Anggara Sari, (2008), Analisis Efektivitas dan Kontribusi Penerimaan Pajak Bumi dan Bangunan Terhadap Pendapatan Daerah di Kota Bandung. Jurnal Wacana Kinerja. Volume XIII, No. 2 November 2010. Halaman 173-185. Diakses pada tanggal 3 Oktober 2017, pada http://isjd.pdii.lipi.go.id/admin/jurnal/ 13210173185.pdf 